\title{
Social capital, economic capital and power: further issues for a public health agenda
}

Lynch et al offer a rejoinder to my editorial and argue for "a neo-material basis for health in the 21 st century". ${ }^{1}$ In their article they claim that my editorial rejected a materialist view of health inequities and promoted instead a psychosocial perspective on health inequities. While I find myself in agreement with much of the thrust of the argument of Lynch et al concerning the importance of material factors to health, I think their critiques of my piece are largely unsubstantiated. In the following reply I dispute some of their claims about my editorial, offer support to much of their argument and suggest that both my original editorial and their rejoinder failed to pay attention to the role of power in producing and continuing economic, social and health inequities.

I am glad that my editorial has sparked the interest of thoughtful public health researchers. That was my intention in writing it. Social capital literature is growing apace. Winter ${ }^{2}$ reports that before 1981 the number of journal articles listing social capital as an identifier totalled 20. Between 1991 and 1995 there were 109 listings and from 1996 to March 1999 there were 1003 listings. The term is being used in a range of policy settings including by local, state and national governments and by international organisations such as the World Bank. In this context it is vitally important that public health enters the theoretical debate more rigorously than it has to date. My editorial was a short piece (in fact about half the length of the rejoinder) in which I sought to offer some warnings to the public health community about an unquestioning acceptance of the notion of social capital and, in particular a view of social capital that did not consider its interaction with economic factors and that took an atheoretical approach to the concept.

There are few bones to pick with Lynch et al, however. Social capital is a hotly disputed concept. There is confusion and little terminological precision and theoretical rigour $^{3}$ in much of the debate about social capital. I'm afraid that Lynch et al also fall into this trap. They state "In contrast, Baum, has stated elsewhere that, 'Most definitions agree that civil society is not market or government activity'. We disagree with Baum's summary of the available definitions and think that such a circumscribed view of social capital will severely limit its potential relevance for public health". Here Lynch et al are assuming that civil society and social capital are synonymous, which, of course, they are not. My editorial noted the need for a complex understanding of the definition of social capital and that its meaning is very much disputed. While civil society is set aside from the government and the market this does not mean it is not strongly influenced by both. They are intimately related. Government policies will have a direct effect on civil society, particularly in terms of the extent to which governments are prepared to pursue policies that control markets, re-distribute income and wealth and create a society in which trust and cooperation can flourish. In the Australian context $\mathrm{Cox}^{4}$ has argued that the mark of a truly civil society is one in which governments do intervene to redress the excesses of the market.
Lynch et al claim that I "perpetuate the idea that absolute income levels and material standards of living are not important for health in developed countries". Yet a re-reading of my editorial does not offer any support for this claim. In other, more extended writings I have made quite the opposite points. ${ }^{5}$ Explicitly my editorial stated that "there are dangers that the promotion of social capital may be seen as a substitute for economic investment in poor communities particularly by those governments who wish to reduce government spending ...”. Hardly a denial of the importance of material standards of living. True I say that there is no direct correlation between GDP and life expectancy but the data supplied by Lynch et al verify this. There is certainly a correlation but it is not direct. Otherwise why do Greece and Japan, for instance, with a lower GDP than the USA have higher life expectancy?

Lynch et al also claim that my editorial supports a shift from material to psychosocial causes of health inequalities. In contrast, I emphasised the importance of economic development and public policy as a means of promoting equity and stated that an understanding of the impact of macro-economic policies on aspects of civil society would be crucial to a public health agenda in the next century. I agree with Lynch et al that there are some worrying signs of a shift towards a reliance on psychosocial causes of health inequities but I do not think there is evidence of this in my editorial.

In fact I wholeheartedly support the advocacy of Lynch et al of the importance of material standards of living and absolute income to health. Thus I agree with Portes and Landolt ${ }^{6}$ warning that "It is not the lack of social capital, but the lack of objective economic resources-beginning with decent jobs - that underlines the plight of impoverished urban groups". But I don't agree with a simplistic materialism that does not consider the impact of forces other than those determined by economic factors on individual and population health. I would like to think that any neo-materialism includes a careful consideration of the pathways by which material deprivation leads to poor health. For instance in developed countries almost universally women live in greater poverty than men yet, overall live longer. While the dynamics of class and gender have been very sparsely researched ${ }^{7}$ it is evident that gender also mediates material conditions of life.

It is also important to consider the means by which material living conditions have been improved in the past. Szreter provides an eloquent analysis of the impact of the industrial revolution in the United Kingdom at the end of the 19th century. He argues that it is not only development that is important to health (and of course part of this is rising material standards of living) but also what collective political decisions are made about what to do with the fruits of development. He shows that collective action and collective struggle played a crucial part in bringing the reforms that underpinned the so called first public health revolution. This analysis immediately alerts us to the important fact that economic growth will not, on its own, deliver good health. This realisation is important in an age dominated by a globalised world view that sees economic 
development as good in and of its self. I would not like to see a neo-materialism unwittingly support such a view. For the 21 st century we have to develop a basis for health for all that challenges unthinking and unfettered economic growth (the hallmark of capitalism) and that seeks a new world order that will redistribute income and wealth. This is self evidently about more than psychosocial factors, although these may play some part in translating economic disadvantage into health status.

Obviously, the crucial concept that both my original editorial and the rejoinder by Lynch et al avoided was power. Yet underlying the debates canvassed in both our pieces are questions about the distribution and maintenance of power in capitalist societies. Szreter's suggests that the economic fruits of development and colonialism in 19th century Britain were put to good use partly because a power struggle took place between competing interests. For Bourdieu, ${ }^{9}$ the French sociologist, social capital is a means of getting access, through social connections, to the economic and cultural resources which are keenly sought in capitalist societies. In other words he sees social capital as one means by which people compete in class competition. So just as some classes have more economic capital so they also have more social capital. Bourdieu's neo-Marxist interpretation of social capital is markedly different to that of Putnam, ${ }^{10}$ the North American sociologist whose pluralist account of social capital puts far more emphasis on trust, norms and networks and their capacity to contribute to economic and democratic development. These different approaches clearly show the importance of theoretical position in the interpretation of the part social capital might play in the production of health. Bourdieu's account leaves no doubt that social capital plays a key part in shaping and perpetu- ating patterns of economic inequity and in re-inforcing the material disadvantaged suffered by many within advanced capitalist societies.

I welcome the contribution of Lynch et al to the debate on social capital and health. I do not think our positions differ as greatly as they imagine. I look forward to further debate and particularly attempts to harness the rich theories other disciplines provide us with so that public health thinking and theorising about social capital becomes more sophisticated. For if we are to achieve greater equity in the 21 st century we will need more than a neo-materialist explanation for health inequities and will have to underpin this with an understanding of the economic imperatives that shape the distribution of all forms of capital.

FRAN BAUM

Department of Public Health, The Flinders University of South Australia, Adelaide, Australia

1 Lynch J, Due P, Muntaner C, et al. Social capital-Is it a good investment strategy for public health? F Epidemiol Community Health 2000;54:404-8.

2 Winter I. Literature survey. In: Winter I, ed. Social capital and social policy in Australia. Melbourne: Australian Institute of Family Studies, 2000.

3 Lenci S. Social capital? From pizza connection to collective action. An inquiry into power, culture and civil society. The Hague: Netherlands Institute of into power, culture and civil
Social Studies, 1998:24.

4 Cox E. A truly civil society. Sydney: Australian Broadcasting Corporation Books, 1995.

5 Baum F. The new public health: the Australian experience. Melbourne: Oxford University Press, 1998

6 Portes A, Landolt P. The downside of social capital. The American Portes A, Landolt P. The downside of social capital. The Ame
Prospect, 1996;26 May-June: (http://epn.org/prospect/26/26-cnt2)

7 Macintyre S, Hunt K, et al. Gender difference in health: are things really as simple as they seem? Soc Sci Med 1995;42:617-24.please give third authors

8 Szreter S. Rapid population growth and security: urbanisation and economic growth in Britain in the nineteenth century. Cambridge: Centre for History and Economics, King's College Cambridge, 1995.

9 Bourdieu P. The forms of capital. In: Richardson J, ed. Handbook of theory and research for the sociology of education. New York: Greenwood Press, 1986.

10 Putnam R. Making democracy work: civic traditions in modern Italy, Princeton, NJ: Princeton University Press, 1993. 